\title{
Time-varying Investment Barriers and Closed-end Country Fund Pricing
}

\author{
Andrew Marshall ${ }^{1}$, John Davies ${ }^{1}$, and M. Fletcher
}

${ }^{1}$ University of Strathclyde Department of Accounting and Finance

\begin{abstract}
We examine the effect of time-varying investment barriers on the pricing of UK closed-end emerging market country funds. We find that a direct measure of capital market segmentation is significantly negatively related to both country fund stock return and Net Asset Value (NAV) return of the fund, but there is no relation to the premium. Also we find some evidence of a positive relation for an indirect barrier (inflation variability) and stock return, NAV return and the premium. Overall our results support an information hypothesis of the impact of investment barriers on closed-end fund pricing.
\end{abstract}




\section{Introduction}

Closed-end country funds offer an opportunity for 'stay-at-home' investing abroad. But what happens when investment barriers make foreign investment less accessible? The traditional explanation associated with Bonser-Neal et al. (1990) is that investment barriers have led to higher premiums ${ }^{1}$ as investors are willing to pay more to invest in an otherwise inaccessible market, raising the share price of the fund. In an era of liberalised markets, we suggest that an information hypothesis is more relevant, where investors respond negatively to information about increases in market inaccessibility. In this paper our contribution is to bring together both the topics of market integration and segmentation and closed-end fund pricing to examine the effect of time-varying direct and indirect investment barriers on the pricing of UK closed-end country funds in emerging markets. ${ }^{2}$ We argue that closedend country fund pricing reflects the information asymmetries between home and foreign investors who are constantly adjusting to information both about their own markets and the foreign market. Extending the 'information explanation' of Froot and Ramadorai (2008) we suggest that investors both at home and abroad respond positively (negatively) to the information conveyed by increases (decreases) in foreign market openness and that this affects both the country fund net asset value (NAV) return and the share price return.

\footnotetext{
${ }^{1}$ A premium results when the share price is above the NAV, and a discount (negative premium) occurs when the share price is below the NAV. Here we use one term 'premium' to refer to both positive and negative premiums (discounts).

${ }^{2}$ For recent evidence on closed-end fund pricing see Bredin et al. (2014) and Alexander and Peterson (2016).
} 
Our paper further contributes by applying a time-varying measure for market segmentation, consistent with the arguments of Bekaert and Harvey (1995), who find that the liberalisation of equity markets is not a once-for-all occurrence. We use a measure that indicates the proportion of the market that is inaccessible to foreigners. Bekaert et al. (2011) argue that this measure is 'the single most important economic explanatory variable, accounting for the largest share of the explained segmentation variance' (p. 3877).

We hypothesise that increasing market segmentation affects closed-end country fund pricing as the value of the underlying assets decreases as local investors absorb the negative information being sent out by their markets. This results in a drop in the NAV. For a brief period there can be very high premiums (consistent with Chandar and Patro, 2000) but then the stock price adjusts downwards as domestic investors react to the loss in value of the underlying assets. Therefore we test three hypotheses on the impact of direct barriers on closed-end stock price return, NAV return and premium:

Hypothesis 1: Direct investment barriers are negatively related to the closed-end fund stock price return;

Hypothesis 2: Direct investment barriers are negatively related to the closed-end fund NAV return;

Hypothesis 3: The closed-end fund premium is not significantly related to direct investment barriers.

Indirect investment barriers can also deter investors from investing in foreign markets (Carrieri et al., 2013). Several studies have also looked at the role of indirect barriers in the pricing of closed-end country funds with conflicting results. Following 
these studies of indirect investment barriers, we also include measures that estimate the illiquidity, inflation variability and lack of economic freedom as indirect investment barriers.

In summary the main contributions of our study are that we find direct investment barriers continue to impact the pricing of emerging closed-end country funds even after the countries have officially liberalised. An increase in market inaccessibility is consistently accompanied by a significant decrease in the stock price return and the NAV return of UK closed-end country funds. Our results show that both foreign and home investors react negatively to decreases in market accessibility and that this decreases both the NAV and the stock price. Although there can be a temporary effect on the premium, as both the NAV and stock price decrease, we do not find a significant long term relation between the premium and direct investment barriers. If we were to restrict our analysis to examining the premium alone, as is the case with most closed-end fund studies, the pricing reactions in the stock price and the NAV would be hidden. Finally we find some evidence of a positive relation for one of our indirect barriers (inflation variability) and stock price, NAV return and premium.

The remainder of this paper is organised as follows: Section 2 describes our data. Section 3 presents the empirical results and Section 4 the robustness tests on our results. Section 5 concludes.

\section{Data}

We collect monthly data from Datastream on the complete sample of seventeen UK traded closed-end country funds investing in single emerging markets from 31 
December 1993 to 31 December 2009. We define the closed-end fund premium in equation (1) as the difference between the natural log of the fund stock price and natural $\log$ of the NAV:

$$
\text { PREM } \equiv \text { lnShareprice }-\ln N A V
$$

We use a time varying measure of investment restriction, Edison and Warnock (EW) (2003), to represent the level of capital control exercised by a country. This measure indicates the proportion of the stock market that is inaccessible to foreign investors. We appreciate that a situation could occur in which the overall market value of the market has increased without the investable portion increasing, giving the impression that there has been a relative increase in market restrictions. However, we feel it is reasonable to assume that the stocks available for foreigners are usually the major companies and therefore among the most liquid, and therefore they will increase along with the remainder of the market.

For our three indirect investment barriers we firstly, adapt the Amihud (2002) illiquidity measure in equation (2) to proxy the monthly illiquidity of the foreign market:

$$
C I L L I Q_{c, t}=\sum_{d=1}^{D t}\left|R_{c, d}\right| / V O L_{c, d}
$$

where $C I L L I Q_{c, t}$ is the illiquidity of market $c$ at time $t$. The daily absolute return and daily sterling volume of country equity index $c$ on day $d$ are given by $R_{c, d}$ and $V O L_{c, d}$. Secondly, inflation variability (VINFL) is proxied by the standard deviation of the monthly inflation rate from the IMF International Financial Statistics using a 3 year rolling period ending in month $t$ (Nishiotis, 2004). Thirdly, we use the Economic 
Freedom of the World Index (Gwartney and Lawson, 2013) creating a measure of the lack of economic freedom, or the economic freedom barrier (EFB).

We test for a relation between the components of fund premium, i.e. the stock price and NAV, and the direct and indirect capital control barriers in equation (3):

$$
\begin{aligned}
& \operatorname{SPRET}_{f, c, t}=\alpha_{f}+\beta_{1} E W_{c, t}+\beta_{2} \text { CILLIQ }_{c, t}+\beta_{3} E F B_{c, t}+\beta_{4} \operatorname{VINFL}_{c, t}+ \\
& \beta_{5} \mathrm{UKMKT}_{t}+\beta_{6} \mathrm{UKPREM}_{t}+u_{f, c, t}
\end{aligned}
$$

where $S P R E T_{f, c, t}$ is the return on the stock price of fund $f$ from market $c$ at time $t, \alpha_{f}$ is the fixed effects parameter, $E W$ is the measure of capital control, CILLIQ is the country illiquidity measure, $E F B$ is the economic freedom barrier measure, VINFL is the variability of the inflation, UKMKT is the UK market return and UKPREM is the arithmetic average of the discount of UK funds investing in the UK.

Panel A of Table 1 gives summary statistics for the closed-end fund premium of each of the emerging market country funds and also of a complete sample of forty developed market country funds for comparison. Panel A of Table 1 shows that that the mean UK emerging market fund premium is $-14.19 \%$ is lower than the mean UK developed market fund premium which is $-12.21 \%$. This contrasts with the US findings of Nishiotis (2004) and Chan et al. (2008). None of our sample funds has a positive premium. These differences between US and UK funds, as well as the lower volatility of UK funds (not reported), could be explained by difference in ownership between the UK and US funds: UK closed-end funds are dominated by institutional investors which creates less idiosyncratic risk due to noise trading; during our sample period it was also easier to launch a similar new fund in the UK than the US and this competition could keep UK premiums at lower levels. Panel B of Table 1 provides 
summary statistics for the measures of direct and indirect investment barriers. There are clear differences in both the mean and the standard deviation of the indirect investment barriers, with emerging markets having higher and more variable indirect investment than those in developed markets.

\section{Insert Table 1 here}

\section{Results}

Table 2 Panel A shows a significantly negative relation (at 1\% level of significance) between the fund stock price return and the direct level of capital control, regardless of which indirect barrier is included, and in the presence of the control variables (UKMKT and UKPREM). These results for the direct investment barrier are consistent with our information hypothesis 1, that in the post-liberalisation period, investors react negatively to the information conveyed by an increase in market inaccessibility.

Table 2 Panel B shows that the NAV return is also significantly negatively related to the direct investment barriers. This gives support to our hypothesis 2 . We argue that when there is an increase in the EW measure (in other words when the value of the market accessible to foreigners decreases in relation to the entire country market) the market value of the assets the fund has invested in decreases, causing the NAV to decrease. As this measure is a ratio we can envisage a situation where the overall market increases in market value, but the restrictions are unchanged. However, we assume that the market value of the investable portion of the market will generally increase along with the inaccessible portion of the market. In crisis periods this could be different and we consider this in our robustness checks. Table 2 
Panel C provides general support for our hypothesis 3 as there is no consistent relation between the premium and direct investment barriers. ${ }^{3}$ Our findings support Patro (2005) and are also compatible with the concept of temporary premium fluctuation due to sources of investor sentiment such as trades driven by foreign news events, see Hwang (2011).

Table 2 shows that the only indirect barrier to be significant is inflation variability (VINFL), which is positively related to fund stock price, NAV return and also the premium. This indicates that inflation variability is not perceived negatively by closed-end fund investors. In terms of our controls we see a strong positive relation between the stock and NAV return of the fund and the control variable UKMKT (the UK market return). We would expect that the stock price would be strongly positively influenced by the home market and this is consistent with previous studies of closed-end country funds (Bodurtha et al., 1995) and for the NAV return, this indicates a global factor in price movement, even in emerging markets.

\section{Insert Table 2 here}

\section{Robustness checks}

\subsection{Robustness to control variables and crisis periods}

We add a more extensive set of control variables to the regressions from Table 2 including the foreign exchange appreciation rate, foreign market return and log of market value as well as the UK market return and the UK average premium. We also included dummy variables for the East Asian Crisis in 1997-98, the Global

\footnotetext{
${ }^{3} \mathrm{We}$ also regress the share price and NAV return for each fund against the change in the level of the EW measure. We find that there is a significant relation between the share price return and change in EW measure for 5 funds and between NAV return and change in EW measure for 7 funds (results available from authors on request).
} 
Financial Crisis in 2007-2008 and for the period following an index adjustment from November 2008 onwards. The tests with the additional control variables do not change our main results for hypotheses 1 to 3 from Table 2 (available from authors on request).

\subsection{Alternative segmentation measures}

As an alternative measure of segmentation we use the 24 month rolling covariance between the returns of the emerging market invested in by the fund and the world market return (RCOV). Table 3 shows that the level of covariance between the emerging market invested in by the fund and the world market is significantly positively related to the stock price and NAV return of emerging market closed-end funds, but not the premium. This shows that the greater the level of integration the higher the return on the fund and supports the findings from Table 2.

\section{Insert Table 3 here}

We base our second alternative measure on the Lane and Milesi-Ferretti $(2007,2013)$ ratio of the country's aggregate assets plus total liabilities to its gross domestic product. We expect that as a country develops and becomes more open, foreigners increasingly invest and its foreign assets increase relative to its GDP. However, as it develops, the country can also be in a position to borrow more, and so the foreign liabilities will also increase. Therefore we extract from the Lane and Milesi-Ferretti (2013) ratio two separate measures: the total foreign assets in relation to GDP (TFA/GDP) and total foreign liabilities in relation to GDP (TFL/GDP). Table 4 shows a consistently significant relation between the stock price and NAV return and both measures of country openness. This supports our previous findings that the stock price and NAV return are significantly related to measures of country 
openness. The more (less) open a country becomes, the higher (lower) is the fund (NAV) return of the corresponding closed-end country fund. Generally this gives support to the information hypothesis that investors respond positively to the information conveyed by greater market openness and that this is reflected in the pricing.

\section{Insert Table 4 here}

\section{Conclusion}

In this paper we find that direct measures of capital market segmentation are significantly negatively related to both country fund stock return and NAV return. The lower the level of capital control and the higher the level of integration, the higher the stock price and NAV return of UK closed-end funds in emerging markets. Our results support an information hypothesis, whereby investors are responding positively (negatively) to increases (decreases) in market accessibility. This points the way towards a richer understanding of the closed-end fund premium - examined less as an isolated puzzle and more as the fluctuating relation between the expectations of the domestic and foreign investor as they respond to changes in information. We also include proxies for the indirect barriers of country illiquidity, inflation variability and lack of economic freedom. We find that only inflation variability is significantly related to the pricing of UK closed-end funds in emerging markets. We find that it is positively related to the stock price return, NAV return and premium, and suggest that increases in the pricing of closed-end funds which accompany increasing market openness can also accompany increased inflation volatility as emerging markets are more open to capital flows from around the world. 


\section{References}

Alexander, G. J., \& Peterson, M. A. (2016). Short selling and the pricing of closed-end funds. Journal of Financial Markets, In Press, http://dx.doi.org/10.1016/j.finmar.2016.08.001

Amihud, J. (2002). Illiquidity and stock returns: cross-section and time series effects. Journal of Financial Markets, 5, 31-56.

Bekaert, G., \& Harvey, C. R. (1995). Time varying world market integration. The Journal of Finance, 50, 403-444.

Bekaert, G., Harvey, C. R., Lundblad, C. T., \& Siegel, S. (2011). What segments equity markets? Review of Financial Studies, 24, 3841-3890.

Bodurtha, J. N., Kim, D.-S., Lee, C. M. (1995). Closed-end country funds and US market sentiment. Review of Financial Studies, 8, 879-918.

Bonser-Neal, C., Brauer, G., Neal, R., \& Wheatley, S. (1990). International investment restrictions and closed-end country fund prices. Journal of Finance, 45, 523-547.

Bredin, D., Cuthbertson, K., Nitzsche, D., \& Thomas, D. C. (2014). Performance and performance persistence of UK closed-end equity funds. International Review of Financial Analysis, 34, 189-199.

Carrieri, F., Chaieb, I., Errunza, V. (2013). Do implicit barriers matter for globalization. Review of Financial Studies, 26, 1694-1739.

Chan, J. S., Jain, R., \& Xia, Y. (2008). Market segmentation, liquidity spillover, and closedend country fund discounts. Journal of Financial Markets, 11, 377-399.

Chandar, N., \& Patro, D. K. (2000). Why do closed-end country funds trade at enormous premiums during currency crises? Pacific-Basin Finance Journal, 8, 217-248.

Edison, H. J., \& Warnock, F. E. (2003). A simple measure of the intensity of capital controls. Journal of Empirical Finance, 10, 81-103.

Froot, K. A., \& Ramadorai, T. (2008). Institutional portfolio flows and international investments. Review of Financial Studies, 21, 937-971.

Gwartney, J., \& Lawson, R. (2013, March 25). Free the World.Com. Retrieved Aug 31, 2012, from Website of the Economic Freedom Network: http://www.freethworld.com

Hwang, B.-H. (2011). Country-specific sentiment and security prices. Journal of Financial Economics, 100, 382-401.

Lane, P. R., \& Milesi-Ferretti, G. M. (2007). The external wealth of nations Mark II: revised and extended estimates of foreign assets and liabilities, 1970-2004. Journal of International Economics, 73, 223-250.

Lane, P. R., \& Milesi-Ferretti, G. M. (2013). Updated and Extended "External Wealth of Nations" Dataset, 1970-2011. Retrieved from http://www.philiplane.org/EWN.html 
Nishiotis, G. P. (2004). Do indirect investment barriers contribute to capital market segmentation? Journal of Financial and Quantitative Analysis, 39, 613-630.

Patro, D. K. (2005). Stock market liberalization and emerging market country fund premiums. Journal of Business, 78, 135-168. 
Table 1: Summary Statistics for Measures of Direct and Indirect Barriers and Emerging Market Closed-end Funds

\begin{tabular}{|c|c|c|c|c|c|c|c|c|}
\hline \multicolumn{9}{|c|}{ Panel A: Emerging Market Closed-end Fund Summary Statistics } \\
\hline Fund & $\begin{array}{l}\text { Sample } \\
\text { Period }\end{array}$ & $\begin{array}{l}\text { Premium } \\
\text { Average }\end{array}$ & $\begin{array}{l}\text { Premium } \\
\text { Std. Dev }\end{array}$ & \multicolumn{2}{|c|}{ Fund } & $\begin{array}{l}\text { Sample } \\
\text { Period }\end{array}$ & $\begin{array}{l}\text { Premium } \\
\text { Average }\end{array}$ & $\begin{array}{l}\text { Premium } \\
\text { Std. Dev }\end{array}$ \\
\hline Aberdeen New Thai & $\begin{array}{l}12 / 1993- \\
12 / 2009\end{array}$ & -11.90 & 8.95 & \multicolumn{2}{|c|}{ JPMF Indian } & $\begin{array}{l}03 / 1994- \\
12 / 2009\end{array}$ & -10.84 & 11.69 \\
\hline Edinburgh Java & $\begin{array}{l}12 / 1993- \\
05 / 2002\end{array}$ & -9.91 & 12.39 & \multicolumn{2}{|c|}{$\begin{array}{l}\text { Old Mutual } \\
\text { South Africa }\end{array}$} & $\begin{array}{l}06 / 1994- \\
02 / 2007\end{array}$ & -15.75 & 6.33 \\
\hline First Philippine & $\begin{array}{l}12 / 1993- \\
05 / 1997\end{array}$ & -18.64 & 4.28 & \multicolumn{2}{|c|}{$\begin{array}{l}\text { Taiwan } \\
\text { Investment }\end{array}$} & $\begin{array}{l}01 / 1994- \\
07 / 1999\end{array}$ & -18.29 & 9.24 \\
\hline Siam Selective Growth & $\begin{array}{l}12 / 1993- \\
05 / 2000\end{array}$ & -22.19 & 7.63 & \multicolumn{2}{|c|}{ Laxey } & $\begin{array}{l}01 / 1997- \\
09 / 2008\end{array}$ & -30.27 & 18.52 \\
\hline Turkey Trust & $\begin{array}{l}12 / 1993- \\
06 / 1998\end{array}$ & -12.12 & 12.57 & \multicolumn{2}{|c|}{$\begin{array}{l}\text { JPM Russian } \\
\text { Secs }\end{array}$} & $\begin{array}{l}12 / 2002- \\
12 / 2009\end{array}$ & -9.03 & 3.53 \\
\hline INVESCO Korea & $\begin{array}{l}12 / 1993- \\
04 / 1999\end{array}$ & -9.31 & 8.73 & \multicolumn{2}{|c|}{$\begin{array}{l}\text { Korea Europe } \\
\text { Fund }\end{array}$} & $\begin{array}{l}06 / 1989- \\
04 / 2003\end{array}$ & -9.56 & 12.72 \\
\hline New India & $\begin{array}{l}12 / 1993- \\
12 / 2009\end{array}$ & -7.86 & 6.35 & \multicolumn{2}{|c|}{$\begin{array}{l}\text { Korea } \\
\text { Liberalisation }\end{array}$} & $\begin{array}{l}12 / 1992- \\
01 / 1997\end{array}$ & -3.77 & 14.03 \\
\hline China Investment & $\begin{array}{l}12 / 1993- \\
08 / 1998\end{array}$ & -19.49 & 5.53 & \multicolumn{2}{|c|}{ JF Philippine } & $\begin{array}{l}06 / 1994- \\
06 / 1997\end{array}$ & \multirow[t]{4}{*}{-21.85} & 7.89 \\
\hline JP Morgan Chinese & $\begin{array}{l}12 / 1993- \\
12 / 2009\end{array}$ & -8.97 & 10.21 & & & & & \\
\hline $\begin{array}{l}\text { Average Premium } \\
\text { Emerging Funds }\end{array}$ & -14.19 & & & & & & & \\
\hline $\begin{array}{l}\text { Average Premium } \\
\text { Developed Funds }\end{array}$ & -12.21 & & & & & & & \\
\hline Panel B & \multicolumn{2}{|c|}{ EW Measure } & \multicolumn{2}{|c|}{ Country Illiquidity } & \multicolumn{2}{|c|}{$\begin{array}{c}\text { Inflation } \\
\text { Variability }\end{array}$} & \multicolumn{2}{|c|}{$\begin{array}{c}\text { Economic Freedom } \\
\text { Barrier }\end{array}$} \\
\hline Country & Mean & Std. Dev & Mean & Std. Dev & Mean & Std. Dev & Mean & Std. Dev \\
\hline China & 0.66 & 0.21 & 0.00022 & 0.00065 & 5.12 & 6.12 & 4.05 & 0.48 \\
\hline India & 0.57 & 0.19 & 0.00011 & 0.00025 & 6.85 & 2.36 & 3.77 & 0.42 \\
\hline Indonesia & 0.19 & 0.18 & 0.00057 & 0.00056 & 12.62 & 7.14 & 3.74 & 0.25 \\
\hline Korea, South & 0.28 & 0.35 & 0.00004 & 0.00007 & 3.96 & 1.17 & 2.99 & 0.41 \\
\hline Philippines & 0.47 & 0.07 & 0.00083 & 0.00064 & 5.98 & 2.10 & 3.22 & 0.35 \\
\hline Russia & 0.27 & 0.15 & 0.0655 & 0.52000 & 134.96 & 221.34 & 4.34 & 0.95 \\
\hline South Africa & 0.01 & 0.01 & 0.00008 & 0.00007 & 7.01 & 2.25 & 3.29 & 0.43 \\
\hline Sri Lanka & 0.65 & 0.11 & 0.00011 & 0.00025 & 10.28 & 2.27 & 3.99 & 0.3 \\
\hline Taiwan & 0.45 & 0.29 & 0.00002 & 0.00001 & N/A & N/A & 2.62 & 0.18 \\
\hline Thailand & 0.49 & 0.13 & 0.00032 & 0.00042 & 3.66 & 1.59 & 3.24 & 0.23 \\
\hline Turkey & 0.02 & 0.02 & 0.00025 & 0.00044 & 52.63 & 30.78 & 4.02 & 0.57 \\
\hline Average Emerging Markets & 0.37 & 0.16 & 0.00618 & 0.0476 & 24.31 & 27.71 & 3.57 & 0.42 \\
\hline Average Developed Markets & & & 0.00006 & 0.00005 & 2.02 & 0.66 & 7.77 & 0.23 \\
\hline
\end{tabular}

Panel A of Table 1 reports summary statistics of direct and indirect investment barriers between 31/12/1993 and $31 / 12 / 2009$. The Edison Warnock monthly capital control measure is the ratio of the S\&P Investable Index to the S\&P Global Index for the country market. Country illiquidity is measured as the absolute monthly return of the country market divided by the sterling volume of trading over the same period. Inflation variability is calculated using a three-year rolling period. Economic freedom is calculated using the annual measures from the Economic Freedom of the World (Fraser Institute). Panel B reports the sample period and summary statistics of the premium $(100 *(\operatorname{lnSP}-\operatorname{lnNAV}))$ of UK closed-end emerging market country funds. 
Table 2: Panel Regression of Country Fund Stock Price Return, NAV Return and Premium with Direct and Indirect Investment Barriers

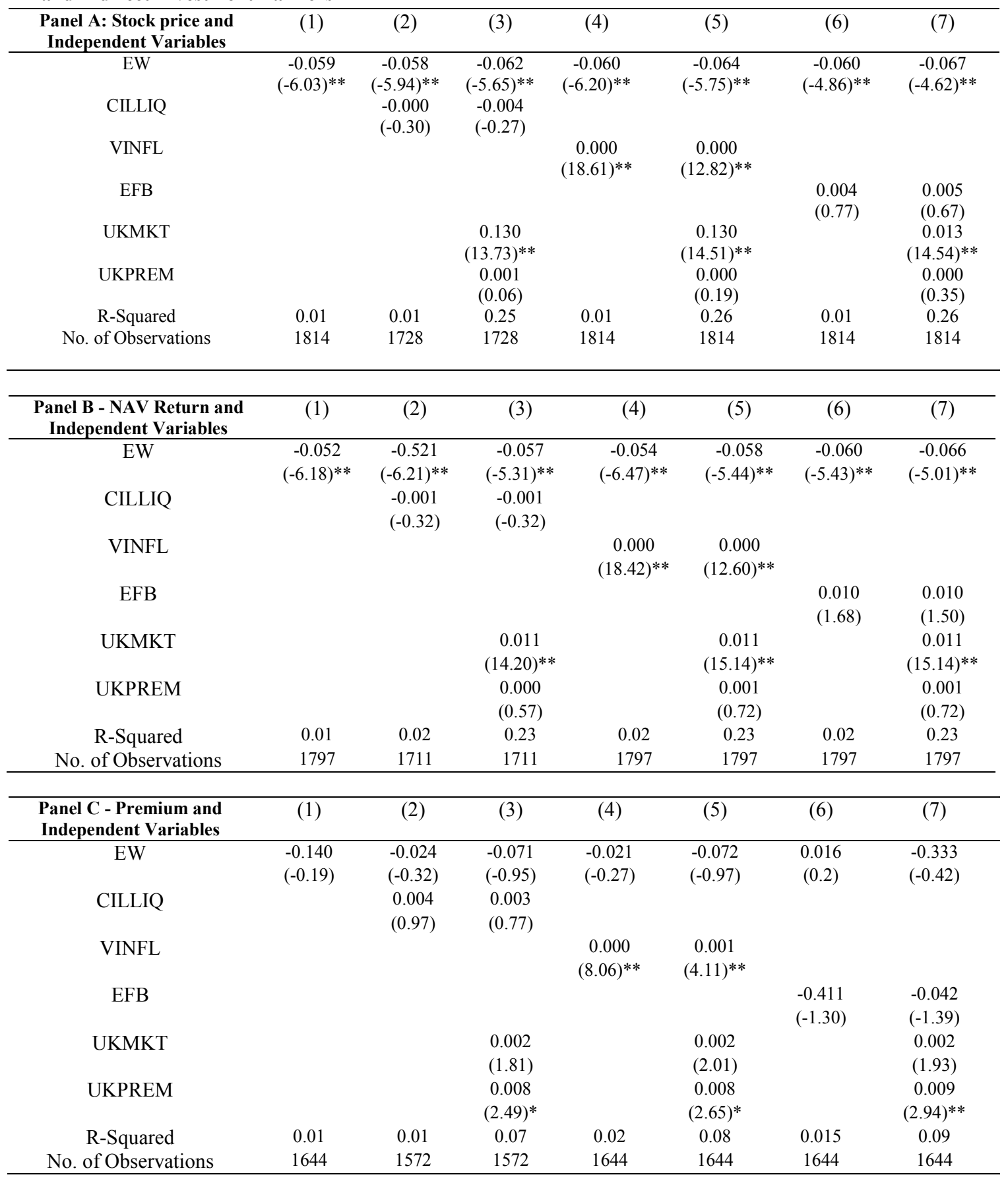

This table reports coefficient estimates from regressions of closed-end fund stock price return, NAV (Net Asset Value) return and closed end fund premium on direct and indirect investment barriers and control variables. The direct barrier is the Edison and Warnock (2003) measure defined as: $E W_{i, t}=1-\frac{M C_{i, t}^{I F C I}}{M C_{i, t}^{I F C G}}$ $E W_{i, t}$ is the EW measure of a country $i$ 's restrictions on foreign ownership at time $t$ which relates the total market capitalisation of the global market of that country (IFCG) to the capitalisation of that market that is accessible to foreign investors (IFCI). Indirect barriers and control variables are defined in the paper. In order to take account of heterogeneity between the funds, we use country closed-end fund fixed effects (Petersen, 2009). We use robust standard errors to correct for heteroskedasticity. The corresponding t-statistics are reported in parentheses. The symbol * denotes significance at the $5 \%$ level and $* *$ denotes significance at the $1 \%$ level. 
Table 3: Panel Regression of Country Fund Stock Price Return, NAV Return and Premium with World Market Covariance and Indirect Investment Barriers

\begin{tabular}{lccccccccc}
\hline & \multicolumn{3}{c}{ Panel A: Stock Price Return } & \multicolumn{5}{c}{ Panel B: NAV Return } & \multicolumn{3}{c}{ C: Premium } \\
\hline & $(1)$ & $(2)$ & $(3)$ & $(4)$ & $(5)$ & $(6)$ & $(7)$ & $(8)$ & $(9)$ \\
RCOV & 5.00 & 4.63 & 4.33 & 4.99 & 4.59 & 4.51 & 0.15 & 0.89 & -0.63 \\
& $(2.88)^{*}$ & $(2.83)^{*}$ & $(2.53)^{*}$ & $(3.03)^{* *}$ & $(3.20)^{* *}$ & $(2.90)^{*}$ & $(0.04)$ & $(0.24)$ & $(-0.17)$ \\
CILLIQ & -0.04 & & & -0.04 & & & 0.07 & & \\
& $(-5.77)^{* *}$ & & & $(-6.33)^{* *}$ & & & $(5.15)^{* *}$ & & \\
VINFL & & -0.00 & & & -0.00 & & & 0.01 & \\
& & $(-0.39)$ & & & $(-0.52)$ & & & $(0.76)$ & \\
EFB & & & -0.01 & & & -0.00 & & & -0.06 \\
& & & $(-1.22)$ & & & $(-0.26)$ & & & $(-2.55)^{*}$ \\
UKMKT & 0.01 & 0.01 & 0.01 & 0.01 & 0.01 & 0.01 & 0.00 & 0.00 & 0.00 \\
& $(10.36)^{* *}$ & $(10.79)^{* *}$ & $(10.78)^{* *}$ & $(10.35)^{* *}$ & $(10.88)^{* *}$ & $(10.83)^{* *}$ & $(2.29)^{*}$ & $(1.77)$ & $(1.82)$ \\
UKPREM & -0.00 & -0.00 & -0.00 & 0.00 & 0.00 & -0.00 & 0.01 & 0.01 & 0.01 \\
& $(-0.07)$ & $(-0.42)$ & $(-0.32)$ & $(0.56)$ & $(0.79)$ & $(-0.30)$ & $(2.63)^{*}$ & $(2.69)^{*}$ & $(2.75)^{*}$ \\
& & & & & & & & & \\
R-Squared & 0.25 & 0.24 & 0.24 & 0.23 & 0.22 & 0.21 & 0.10 & 0.07 & 0.09 \\
No. of & & & & & & & & & \\
Observations & 1749 & 1767 & 1767 & 1732 & 1750 & 1750 & 1593 & 1597 & 1597 \\
\hline
\end{tabular}

This table reports coefficient estimates from regressions of closed-end fund stock price return, NAV return and premium on world market covariance, indirect investment barriers and various control variables. RCOV is a 24 month rolling covariance between the return on the world market and the return on the emerging market corresponding to each fund. Indirect barriers and control variables are defined in the paper. In order to take account of heterogeneity between the funds, we use country closed-end fund fixed effects (Petersen, 2009). We use robust standard errors to correct for heteroskedasticity. The corresponding $\mathrm{t}$-statistics are reported in parentheses. The symbol * denotes significance at the 5\% level and ** denotes significance at the $1 \%$ level. 
Table 4: Panel Regression of Country Fund Stock Price Return, NAV Return and Premium with Lane Milesi-Ferreti Market Openness Measure

\begin{tabular}{|c|c|c|c|c|c|c|c|c|c|c|c|c|}
\hline & \multicolumn{4}{|c|}{ Panel A: Stock Price Return } & \multicolumn{4}{|c|}{ Panel B: NAV Return } & \multicolumn{4}{|c|}{ Panel C: Premium } \\
\hline & (1) & (2) & (3) & (4) & (5) & (6) & (7) & (8) & $(9)$ & $(10)$ & $(11)$ & (12) \\
\hline \multirow[t]{2}{*}{ TFA/GDP } & 1.25 & 0.98 & & & 1.15 & 0.99 & & & 0.10 & 0.23 & & \\
\hline & $(4.01)^{* *}$ & $(3.05)^{* *}$ & & & $(3.35)^{* *}$ & $(2.67)^{*}$ & & & 1.54 & $2.97 * *$ & & \\
\hline \multirow[t]{2}{*}{ TFL/GDP } & & & 0.87 & 0.70 & & & 0.92 & 0.82 & & & 0.09 & 0.17 \\
\hline & & & $(2.40)^{*}$ & $(2.01)^{*}$ & & & $(2.75)^{*}$ & $(2.48)^{*}$ & & & 1.83 & $(3.72)^{* *}$ \\
\hline \multirow[t]{2}{*}{ UKMKT } & & -0.00 & & -0.01 & & -0.00 & & -0.00 & & 0.00 & & 0.00 \\
\hline & & $(-1.70)$ & & $(-3.72)^{* *}$ & & $(-0.93)$ & & $(-2.88)^{*}$ & & $(1.52)$ & & $(1.06)$ \\
\hline \multirow[t]{2}{*}{ UKPREM } & & -0.02 & & -0.02 & & -0.01 & & -0.01 & & 0.01 & & 0.01 \\
\hline & & $(-2.31)^{*}$ & & $(-2.38)^{*}$ & & $(-1.58)$ & & $(-1.46)$ & & $(2.40)^{*}$ & & $(2.62) *$ \\
\hline No. of Observations & 161 & 161 & 161 & 161 & 163 & 163 & 163 & 163 & 153 & 153 & 153 & 153 \\
\hline R-Squared & 0.13 & 0.15 & 0.11 & 0.15 & 0.11 & 0.12 & 0.12 & 0.14 & 0.02 & 0.11 & 0.02 & 0.12 \\
\hline
\end{tabular}

This table reports coefficient estimates from regressions of closed-end fund stock price return, NAV return and premium on the two components of the Lane Milesi-Ferreti Openness Measure. In specifications (1), (5) and (9) we regress Fund Stock Price Return, NAV Return and Premium with the Total Foreign Assets divided by the GDP of each country (TFA/GDP). In specifications (3), (7) and (11) we regress Fund Stock Price Return, NAV Return and Premium with the Total Foreign Liabilities divided by the GDP of each country (TFL/GDP). In specifications (2), (4), (6), (8), (10) and (12) we include the UK market return (UKMKT) to control for movement in the UK market that can affect closed-end fund pricing and the UK average premium to control for investor sentiment. In order to take account of heterogeneity between the funds, we use country closed-end fund fixed effects (Petersen, 2009). We use robust standard errors to correct for heteroskedasticity. The corresponding t-statistics are reported in parentheses. The symbol

$*$ denotes significance at the $5 \%$ level and $* *$ denotes significance at the $1 \%$ level. 